\title{
OBSZARY WYKLUCZENIA SPOŁECZNEGO W II RZECZYPOSPOLITEJ ${ }^{1}$
}

\section{Mateusz Rodak}

http://orcid.org/0000-0003-4665-6833

Instytut Historii im. Tadeusza Manteuffla PAN w Warszawie

\begin{abstract}
\section{AREAS OF SOCIAL EXCLUSION IN THE SECOND POLISH REPUBLIC}

Finding the answer to the question of what defines social norms in complex historical communities, such as states, nations and social strata can sometimes help understand the rules that they were governed by. This becomes possible by means of research, the aim of which is to reconstruct the areas of social exclusion specific to the particular epoch, that is, the zones where the so-called "statutory indeterminacy" can be observed. Some of the effects of this phenomenon may include the processes of social exclusion. In the paper submitted here, I make an attempt to indicate and describe typical areas of the Second Polish Republic that were conducive to social deprivation. The criteria that guided my choices included, first and foremost, the actual impact on the nature of the social relations and, secondly, their mass scale. In my research I use two essential terms, namely, social exclusion, understood as the state of "non-participation of an individual/family or group in various areas of social life" and margins of society, described both as "structural margins", after Zbigniew Galor, and as "social margins". Among the causes leading to the sense of social exclusion I distinguish, 1) the privileged position the Roman Catholic faith and ethnic Poles as representatives of the dominant nation; 2) the standards of exercising political power, especially those adopted after 1926; 3 ) the civilizational differences; 4) the gap between the centre and the periphery; 5) disparity in the access to health care and social services, etc. Of key importance to some of these processes were, in my opinion, the economic issues, mainly related to restrictions on access to the labour market resulting in increased unemployment and poverty, as well as homelessness and, in the extreme cases, dysfunctional behaviours. I also emphasise the significant impact of the Great Depression on the phenomena that I describe. At the same time, I make an attempt to counterbalance this description with some positive processes in the Second Republic that favoured social inclusion (e.g. universal education and the military service). In conclusion I advance the thesis that despite the significant
\end{abstract}

${ }^{1}$ Artykuł powstał w ramach realizacji grantu finansowanego przez Narodowe Centrum Nauki (grant: „Biologiczny standard życia w Polsce 1800-1950. Przemiany wysokości i masy ciała”, nr 2016/21/B/ HS3/00028).

Adres do korespondencji: mateuszrodak@yahoo.pl 
progress of modernisation, interwar Poland was a state with an excess of processes that favoured the broadly understood exclusion.

Keywords: social exclusion, marginalisation, Second Polish Republic, margins of society, unemployment, homelessness, crime.

Słowa kluczowe: wykluczenie społeczne, marginalizacja, II Rzeczpospolita, margines społeczny, bezrobocie, bezdomność, przestępczość.

Karanej dwukrotnie za oszustwo i fałszerstwo Helenie Zofii Kisielnickej w sierpniu 1933 roku w stołecznym Urzędzie Śledczym polecono spisać życiorys. Była już wówczas urzędniczka, zatrudniona wcześniej między innymi w Ministerstwie Rolnictwa, zanotowała:

W r. 1930 miałam wytoczoną sprawę o szantaż, od tego czasu, wobec zupełnego dyskredytowania mię przez prasę, która ze specjalną złośliwością występowała przeciwko mnie, nie mogłam nigdzie zwrócić się o pomoc [...] gdyż wszyscy mi odmawiali, mając w pamięci ciągle drukowane moje zdjęcie. Borykałam się bardzo z matką, mieszkając kątem u swej kuzynki [...]. Obecnie wzięłam mieszkanie na Żoliborzu do spółki z bratem ciotecznym i bratową. Postanowiłam 1 pokój wynająć na 2 osoby z utrzymaniem i wydawać obiady. Lecz brak było na wszystko funduszy, a pomocy znikąd. Znosiłam to wszystko aż do czasu nastania mrozów styczniowych, kiedy w mieszkaniu zapanował mróz, że ze ścian sypały się kropelki lodu, a matka poodmrażała sobie ręce i nogi. Wtedy postanowiłam za wszelką cenę zdobyć trochę gotówki na opał i na rozpoczęcie wydawania obiadów i wyszła cała ta sprawa, za którą jestem zatrzymana $^{2}$.

Nieznane są prawdziwe przyczyny, dla których „Czarna dama” - takim przydomkiem ochrzciły ją ówczesne czerwoniaki - zdecydowała się żyć z przestępstw. Wydaje się, że kluczowym momentem było zwolnienie z pracy w 1930 roku. Taki też powód sama podawała. Co prawda była już wcześniej karana za drobne oszustwo, niemniej w przeciągu półtora roku od zwolnienia narastała w jej dossier liczba wpisów, z czasem pojawiły się pierwsze i kolejne wyroki. W końcu w 1937 roku została skazana na pięć lat więzienia (wyrok łączny) za dokonane od 1933 roku liczne szantaże, oszustwa, fałszerstwa i kradzieże ${ }^{3}$.

Spisane przez Kisielnicką etapy jej „,moralnego upadku” (tak proces ten nazywała prasa relacjonująca jej kolejne przygody z prawem), wypełniały ramy klasycznej opowieści osób, które doświadczyły społecznej marginalizacji. Proces ten, względnie stan, współcześnie określa się mianem wykluczenia społecznego.

To termin stosunkowo nowy, wprowadzony do dyskursu naukowego dopiero w latach 70. XX wieku. W klasycznej wersji utożsamiany był z biedą. Aktualnie termin ten stosuje się na określenie procesu lub stanu nieuczestniczenia jednostki/ rodziny czy grupy w różnych obszarach życia społecznego. Zastosowanie szerokiej definicji, wbrew moim pierwotnym planom, do czego jeszcze wrócę, pozwala traktować zjawisko ubóstwa jako jeden, ale nie jedyny, z czynników sprzyjających

${ }^{2}$ Archiwum Państwowe w Warszawie (dalej: APW), Urząd Śledczy m.st. Warszawy (dalej: UŚ m.st. W.), Arkusz dossier Heleny Zofii Kisielnickiej, sygn. 866, 1933-1948, k. 24.

${ }^{3}$ Ibidem, k. 3. 
ekskluzji. Za Kazimierzem Frieske wykluczenie społeczne i marginalizację traktuję jako określenia synonimiczne, które służą do nazywania tych samych procesów. W okresie międzywojennym nie funkcjonowało pojęcie wykluczenia. Mówiło się z reguły o marginalizacji, deklasacji, degradacji czy wykolejeniu. Pojęcia te służyły do opisywania przede wszystkim procesu ubożenia, względnie towarzyszących mu jako skutki lub przyczyny przejawów zachowań o charakterze patologicznym. Badając problem wykluczenia, wypada odnieść się do kojarzonego z nim zjawiska, którym jest margines społeczny. W tym miejscu stosuję rozróżnienie na margines strukturalny, który rozumiem jako warstwę społeczną tworzoną przez ludzi przejawiających aspołeczne usposobienie (przede wszystkim przestępcy), oraz margines socjalny, który utożsamiam przede wszystkim ze zjawiskiem „biedy absolutnej”, a w konsekwencji na przykład żebractwem ${ }^{4}$. Poza tymi strukturami za Zbigniewem Galorem lokuję przestrzeń określaną jako „cmentarz socjalny”. Znajdą się tam i nałogowi alkoholicy, i narkomani - osoby bez szans na wyjście z nałogu itd. Przy czym przedstawicieli wszystkich tych struktur łączył fakt, że burzyli konsensus społeczny i budzili wśród tzw. normalsów poczucie zagrożenia. Jego niwelowaniem lub ograniczaniem zajmować miały się organy władzy państwowej lub samorządowej. Margines społeczny to więc tylko jeden z możliwych i nierzadko odwracalnych efektów społecznej ekskluzji.

Niniejszy tekst pozostaje więc skromną i dalece niedoskonałą próbą wskazania wybranych spośród istniejących w II Rzeczypospolitej obszarów społecznego wykluczenia, to jest tych płaszczyzn życia społecznego, w których występowało lub mogło występować zjawisko statusowej nieokreśloności. W „sprzyjających” okolicznościach uruchamiało ono proces(y) wykluczenia ${ }^{6}$, w części zaś przypadków prowadziło na margines społeczny, a w skrajnych na „cmentarz socjalny”.

Patrząc z perspektywy czasu na międzywojenne państwo polskie, bez trudu można dostrzec, jak wiele było w nim sfer życia, w których całe grupy społeczne bądź pojedyncze osoby mogły odczuwać stan tymczasowej, a z czasem i trwałej, jedno-, najczęściej jednak wielowymiarowej deprywacji. Już fakt, że w państwie zdominowanym przez Polaków (rzymskich katolików) pozostałym grupom narodowościowym (wyznaniowym) utrudniano, w różnym oczywiście stopniu, pełne uczestnictwo w życiu politycznym, społecznym, oświatowym czy ekonomicznym, pokazuje

${ }^{4}$ Z. Galor, Margines społeczny a margines socjalny i margines strukturalny. U podstaw socjologii marginalizacji w świetle badań poznańskich z lat 2010-2013 [w:] Życie na skraju. Marginesy spoteczne wielkiego miasta, red. Z. Galor, B. Goryńska-Bittner, S. Kalinowski, Bielefeld 2014, s. 35.

${ }^{5}$ Ibidem, s. 40-41.

${ }^{6} \mathrm{~W}$ tym miejscu należy dodać, że z perspektywy badań historycznych nie sposób rozstrzygnąć dylematu między poczuciem bycia wykluczonym (jednostkowym, często ukrywanym, stanem psychologicznym) a społecznym oglądem rzeczywistości, w której grupy społeczne określają się jako wykluczone lub jako takie są traktowane. Analizę pierwszej ze wspomnianych tu sytuacji umożliwiają m.in. badania memuarystyczne. Otwarte jednak pozostaje pytanie o to, na ile osobiste poczucie wykluczenia przedstawiciela konkretnej grupy społecznej, np. chłopów, można przenosić na całą warstwę. Nawet w sytuacji, w której pamiętnikarz ma tendencję do wypowiadania się w imieniu grupy, której jest członkiem. W tekście wielokrotnie ten zabieg stosuję, mam jednak świadomość, że jest to zabieg pod wieloma względami co najmniej kontrowersyjny. 
skalę problemu ${ }^{7}$. Analizowane przez Kamila Kijka pamiętniki młodych Żydów są wymownym świadectwem skali frustracji będącej reakcją na wykluczenie wielowarstwowe, dosłowne bądź symboliczne ${ }^{8}$. Podobne uczucia musiały towarzyszyć części spośród przedstawicieli pozostałych niepolskich grup etnicznych, które mieszkały w granicach międzywojennej Polski. Dominującą nie tylko w narracji politycznej pozostawała stworzona przez polski ruch narodowy „doktryna polskiej większości”" Obco w polskim środowisku, szkole, urzędzie, w konfrontacji z polskim policjantem, sędzią czy urzędnikiem czuło się wielu Ukraińców, Białorusinów, Żydów czy Niemców. Przy czym część z nich wbrew koncyliacyjnym ${ }^{10}$, w większości nieudanym, próbom łagodzenia poczucia wykluczenia świadomie odmawiała uczestnictwa w realizacji projektu, jakim miało być państwo polskie. W propagowanej przez władze wizji wspólnoty nie chcieli się widzieć i nie widzieli się nie tylko polscy i niepolscy radykałowie z obydwu stron sceny politycznej ${ }^{11}$.

Trudno pominąć praktykę wykluczania z życia społecznego czy politycznego, nierzadko przybierającą formy najbardziej skrajne (więzienie czy śmierć), prawdziwych i wyimaginowanych przeciwników politycznych w ogóle, a także ówczesnej władzy. Dominacja od połowy lat 20. obozu politycznego skupionego wokół J. Piłsudskiego i postępująca redukcja praw obywatelskich wzbudzała wśród części obywateli państwa polskiego poczucie niezaspokojenia fundamentalnego prawa, jakim jest w demokracji między innymi przywilej posiadania własnej reprezentacji politycznej. Otwarte naturalnie jest pytanie, na ile to poczucie było powszechne. Poczynania ówczesnych władz z pewnością były akceptowane przez trudną jednak do określenia część Polaków. Protesty społeczne, które tłumiono krwawo zarówno w latach 20., jak i 30., nie miały wyłącznie wymiaru socjalnego. Adresatem wielu z nich stawali się przedstawiciele władz krajowych czy lokalnych.

${ }^{7}$ Przy czym warto dodać, że obowiązujące wówczas przepisy w zasadzie zakładały równość wszystkich obywateli, bez względu na wyznanie czy narodowość.

${ }^{8} \mathrm{~K}$. Kije k, Dzieci modernizmu. Świadomość, kultura i socjalizacja polityczna młodzieży żydowskiej w II Rzeczypospolitej, Wrocław 2017, s. 274 i n.

${ }_{9}$ P. Brykczyński, Gotowi na przemoc. Mord, antysemityzm i demokracja w międzywojennej Polsce, Warszawa 2017, s. 254. Sformułowanie „doktryna polskiej większości” traktuję w tym miejscu jako sugestywną metaforę opisującą rzeczywistość Polski międzywojennej. Opisywana bowiem przez Brykczyńskiego kwestia dotyczyła w zasadzie przestrzeni parlamentarnej.

${ }^{10}$ Ibidem. Autor pisze o „patriotyzmie inkluzywnym i obywatelskim”, który charakteryzować miał m.in. narracje w kampanii wyborczej z 1922 r. ruchu lewicowego i zwolenników Piłsudskiego. Mowa tu również o działaniach w ramach tzw. eksperymentu wołyńskiego, patrz: W. Mędrzecki, Kresowy kalejdoskop. Wędrówki przez ziemie wschodnie Drugiej Rzeczypospolitej 1918-1939, Kraków 2018, s. 253 i n. Przypomniany ostatnio przez Olgę Linkiewicz casus plebiscytów szkolnych. Patrz: O. Linkiewicz, Lokalność i nacjonalizm. Społeczności wiejskie w Galicji Wschodniej w dwudziestoleciu międzywojennym, Kraków 2018, s. 157 i n.

${ }^{11}$ Równocześnie jednak w wielu miejscach ówczesnego państwa polskiego, określanych mianem pogranicza, funkcjonowały społeczności, które do pewnego momentu tworzyły względnie udany konglomerat narodowościowo-wyznaniowy, wolny od zachowań ekskluzywnych spod znaku podziałów narodowych czy wyznaniowych. Stan ten, jak przekonująco opisuje Olga Linkiewicz, ulegał systematycznej degradacji wraz z polityzacją lokalnego życia społecznego. Por. O. Linkiewicz, op. cit., passim. 
Sytuacja w młodym państwie części przedstawicieli grup narodowościowych innych niż polska bądź przeciwników politycznych, szczególnie po 1926 roku, wytycza ramy zaledwie dwóch obszarów sprzyjających traktowanej szeroko ekskluzji społecznej. Tymczasem wspomnieć w tym miejscu można jeszcze, pozostającą w jakimś stopniu efektem uwarunkowań historycznych, przestrzeń wykluczenia cywilizacyjnego wschodnich, centralnych i południowych rejonów w stosunku do ziem zachodnich, względnie wsi wobec miasta czy szerzej - peryferii wobec centrum ${ }^{12}$. Występujące wówczas różnice $\mathrm{w}$ dostępie do rynku pracy, jego charakterze ${ }^{13}$, wysokości zarobków ${ }^{14}$, nowoczesnych technologii produkcji, nowinek technicznych, opieki medycznej ${ }^{15}$, opieki społecznej, dostępności ubezpieczeń ${ }^{16}$, wymiaru sprawiedliwości, edukacji, kultury, godnych warunków mieszkaniowych to bezdyskusyjny fakt ${ }^{17}$.

Nie ulega też wątpliwości, że wbrew zapisom konstytucji, która stanowić miała o tym, co jest normą, a co nią nie jest, pozycja społeczna kobiet w II RP daleka była, szczególnie z perspektywy środowisk progresywnych, od zadowalającej ${ }^{18}$. Sytuację społeczno-prawną kobiet $\mathrm{w}$ okresie międzywojennym doskonale oddaje tytuł wydanego w 2000 roku zbioru poświęconego tym zagadnieniom - Równe prawa i nierówne szanse. W jakimś stopniu uwagi te dotyczą również osób o odmiennej od akceptowanej wówczas orientacji seksualnej ${ }^{19}$, a także osób starszych (problem szczególnie doskwierający na wsi) czy młodzieży, ludzi chorych lub niedołężnych.

12 Opisując życie społeczności zamieszkującej stołeczną Ochotę w połowie lat 30., Jadwiga Szymanowska ubolewała: „Dodatnie czynniki kultury wielkomiejskiej nie docierają do Ochoty - tylko blichtr zewnętrzny, tylko to co spokojne życie wsi zaraża pośpiechem, blagą, niezaspokojoną żądzą". Por. J. Szymanowska, Peryferyjna dzielnica wielkiego miasta. Próba charakterystyki Ochoty, dzielnicy Warszawy na podstawie badań przeprowadzonych w czasie zapisów szkolnych w 1934 r., „Przegląd Socjologiczny" 1936, nr 1-2, s. 176.

${ }_{13}$ Podstawę gospodarki międzywojennej stanowiła gospodarka drobnotowarowa. Przy czym w województwie śląskim utrzymująca się z niej ludność stanowiła $14,5 \%$, a w województwach północnozachodnich już $85 \%$. W skali całego kraju 60\%. Por. uwagi: C. Le s zc zyń s ka, W. Mę drzeck i, Wstęp [w:] Praca i społeczeństwo Drugiej Rzeczypospolitej, Metamorfozy Społeczne, t. 9, Warszawa 2014, s. 9.

14 Ibidem, s. 10.

15 Pamiętniki chłopów, Warszawa 1935. Bezrolny chłop z powiatu łódzkiego, 1. 34, osiem osób na utrzymaniu, 29 IX 33 r. pisze: „Doktora prawie nie znamy, jeżeli w wypadku pojedzie ktoś po lekarza to jeszcze 15 kilometrów i pan doktor za taką wizytę każe sobie płacić 50 lub 70 zł i przywieź takiego pana i odwieź. Więc lekarza wieś to się boi jak diabła, bo takiego pana widzieć w swoim domu, to kosztuje zaraz jedna krowa, więc tu się jest czego bać!”.

${ }_{16} \mathrm{~K}$. Chylak, Ubezpieczenia społeczne i zaopatrzenia emerytalne w II Rzeczypospolitej, Warszawa 2017, passim.

17 W. Mędrzecki, Materialne uwarunkowania życia spolecznego [w:] Społeczeństwo międzywojenne. Nowe spojrzenie, Metamorfozy Społeczne, t. 10, Warszawa 2015, s. 118.

${ }_{18}$ A. Żarnowska, Obywatelki II Rzeczypospolitej [w:] Równe prawa i nierówne szanse, red. A. Żarnowska, A. Szwarc, Warszawa 2000, s. 296-297; M. Pietrzak, Sytuacja prawna kobiet w Drugiej Rzeczypospolitej [w:] Równe prawa..., s. 91, R. Kny spel-Kopeć, Polityka spoleczna Drugiej Rzeczypospolitej wobec kobiet [w:] Państwo i społeczeństwo Drugiej Rzeczypospolitej, Metamorfozy Społeczne, t. 8, Warszawa 2014, s. 325.

${ }^{19} \mathrm{~W}$ tej sferze podjęto przynajmniej próby prawnego uregulowania Kodeksu karnego z 1932 r., w którym nie znalazła się kara za kontakty homoseksualne. 
Świadomość pozostawania poza obszarem zainteresowania władz państwowych towarzyszyła przedstawicielom licznych grup zawodowych, konsekwentnie przekonanych o swojej gorszej pozycji. Już tylko analiza pamiętników chłopskich dostarcza wielu przykładów rozgoryczenia, które miało wynikać z przeświadczenia o lekceważącym stosunku państwa do włościan ${ }^{20}$. Strajki chłopskie w latach 30. pozostają wymownym przykładem skali frustracji skumulowanej w części rolniczych regionów Polski międzywojennej.

Wiele więc było w II RP sfer życia, w których, w różnym naturalnie stopniu, bez trudu odnajdziemy jednostki lub grupy społeczne przekonane o swojej społecznej nieprzydatności. Doświadczenie deprywacji powodowane również czynnikami niematerialnymi wyjątkowo często było zjawiskiem ponadjednostkowym.

Naturalnie taki obraz społeczeństwa i państwa sprzed 1939 roku pozostawałby dalece niesprawiedliwy. Rozpoczęto, wdrożono lub planowano w II RP wiele inicjatyw, których celem była inkluzja osób czy grup społecznych dotkniętych różnymi formami wykluczenia. Najlepszym tego przykładem pozostaje między innymi reforma edukacji. Jej zasadniczym zadaniem stało się objęcie jak największej liczby młodych obywateli powszechnym obowiązkiem szkolnym. Przy czym należy pamiętać, że w szkole dominować powinna była narracja polska (język i historia), a zasadniczym celem edukacji było wychowanie polskiego patrioty. Wspomnieć należy o zmianach w dostępie do usług medycznych, rozwoju ubezpieczeń społecznych czy innych działaniach w ramach szeroko rozumianej polityki społecznej.

Również zabiegi związane z konsolidacją społeczeństwa, które czyniono w odpowiedzi na dynamicznie zmieniającą się sytuację międzynarodową, a co za tym idzie, rosnące zagrożenie kolejnym konfliktem zbrojnym, można potraktować jako działania o inkluzywnym wymiarze. Ważną rolę nie tylko w procesie socjalizacji, ale również w zakresie niwelowania poczucia dyskryminacji i odrzucenia grywał w przypadku wielu młodych mężczyzn fakt powołania do wojska ${ }^{21}$. Bez należytego wykształcenia, perspektyw, często również pracy, przeświadczeni o swojej zbędności, synowie ówczesnych chłopów czy robotników za sprawą munduru zmieniali swój status, zarówno materialny, jak i społeczny. Jednocześnie moment powrotu do życia w cywilu, szczególnie jeśli służba odbywała się w warunkach frontowych, w wielu przypadkach traktowali jako degradację społeczną. Zaskakująco dużo, jeśli nie większość karier przestępczych w II RP, rozpoczynało się w chwili zwolnienia z wojska i stanowiło efekt systematycznie rosnącego rozgoryczenia ${ }^{22}$. Przypomnieć jednak trzeba w tym miejscu casus fizycznie i psychicznie okaleczonych przez wojnę

${ }^{20}$ Pamiętniki chłopów, Warszawa 1935. Gospodarz 7-morgowy, pow. łaski, 55 lat.

${ }^{21}$ J. Kę sik, Wojsko polskie a społeczeństwo w Drugiej Rzeczypospolitej [w:] Państwo i społeczeństwo Drugiej Rzeczypospolitej, Metamorfozy Społeczne, t. 8, Warszawa 2014, s. 133-134. Pamiętać należy jednak, że w ówczesnym wojsku, choć pełniącym istotną funkcję socjalizacyjną i cywilizacyjną, również bez trudu odnajdziemy elementy o charakterze wykluczającym. Mowa w tym miejscu m.in. o stosunku do poborowych wyznania mojżeszowego, przy czym nie chodzi wyłącznie o casus Jabłonnej z okresu wojny polsko-bolszewickiej. H. Hensche1, Jabłonna als Erinnerungsikone: Juden in den polnischen Streitkräften 1918-1939, „Jahrbuch des Simon-Dubnow-Instituts” 2010, nr 9, s. 570-571.

${ }_{22}$ Tylko tytułem przykładu. APW, UŚ m.st. Warszawy, Arkusz dossier Pawła Ł., 1935-1947, sygn. 1101, k. 2, Arkusz dossier Władysława M., 1931-1947, sygn. 1145, k. 8. 
mężczyzn, którym doświadczenie frontowe na tyle skutecznie przetrąciło życiorysy, że powrót do normy był już po latach 1914-1920 w zasadzie niemożliwy ${ }^{23}$.

Postępująca systematycznie, choć z reguły powoli, modernizacja państwa i społeczeństwa coraz częściej więc w wielu obszarach zaczynała sprzyjać procesom o charakterze inkluzyjnym. Poza tym, co w tym miejscu ma fundamentalne znaczenie, niedostateczne wykształcenie, brak należytej opieki medycznej, zwolnienie z wojska czy konfrontacja z urzędnikiem Polakiem mogły pogłębiać dyskomfort i poczucie obcości, rzadko jednak prowadziły na skraj społeczeństwa, na jego margines ${ }^{24}$. Droga w tym kierunku stawała się bardziej prawdopodobna, gdy wspomnianym tu zjawiskom towarzyszyły okoliczności dosłownie ściągające jednostki czy całe grupy w dół drabiny społecznej ${ }^{25}$.

Tylko bowiem w przypadku jednego obszaru, pomimo licznych wysiłków i rokujących na przyszłość, wówczas jeszcze raczkujących, osiągnięć, trudno mówić o znaczącym sukcesie. Pomijam oczywiście te sfery, w których szanse na powodzenie przed 1939 roku i tak były niewielkie ${ }^{26}$. Obszar, o którym mowa, obejmuje szeroko rozumiany ekonomiczny wymiar ówczesnej rzeczywistości. Przy czym najistotniejszym jego elementem pozostaje międzywojenna bieda - zjawisko nieuznające podziałów etnicznych, religijnych, regionalnych, genderowych czy edukacyjnych.

Stwierdzenie, że międzywojenna Polska była krajem ludzi biednych, to w zasadzie truizm. Świadomość tego mają jednak prawie wyłącznie historycy, stąd nieustannie wypada ten fakt przypominać. Próbę wskazania możliwego ilościowego zasięgu ówczesnej biedy (a nawet nędzy) podjął już wiele lat temu Janusz Żarnowski ${ }^{27}$.

Historyk szacował, że w okresie Wielkiego Kryzysu w stanie „biedy absolutnej” żyć mogło nawet $20 \%$ ówczesnego społeczeństwa ${ }^{28}$. To naturalnie górna granica wyliczeń. W krótkich okresach względnej stabilizacji, a nawet rozwoju ekonomicznego, problemy z zaspokojeniem podstawowych potrzeb biologiczno-społecznych mogło mieć ok. 2 milionów (6-7\%) mieszkańców międzywojennej Polski. Grupę tę tworzyli przedstawiciele miejskich środowisk robotniczych, w tym głównie

${ }^{23}$ K. Si erakow ska, Śmierć, wygnanie, głód $w$ dokumentach osobistych. Ziemie polskie $w$ latach Wielkiej Wojny 1914-1918, Warszawa 2015, s. 132-133.

${ }^{24}$ Por. uwagi na temat niematerialnych przyczyn deprywacji: P. Sałustowicz, op. cit., s. 60. Nierzadko mogła również mobilizować i prowadzić do sytuacji zgoła odmiennych, np. aktywnego uczestnictwa w organizacjach narodowych czy samokształcenia.

${ }^{25}$ P. Sałustowicz, op. cit., s. 61.

${ }^{26}$ A. Chojnowski, Koncepcje polityki narodowościowej rząów polskich w latach 1921-1939, Wrocław-Warszawa-Kraków-Gdańsk 1979, s. 240-241.

27 J. Żarnowski, Bieda i dostatek 1918-1939, [w:] Nędza i dostatek na ziemiach polskich od średniowiecza po XX wiek, red. J. S z te tyłła, Warszawa, 1992, s. 248. Przy czym przez biedę rozumiał „niedostatek środków materialnych umożliwiających utrzymanie minimalnego poziomu życia przyjętego w danej warstwie społecznej”. Nędzę zaś, a więc skrajną formę biedy, kojarzył J. Żarnowski ze stanem „mniej lub bardziej ostrego braku czynników potrzebnych do fizycznej egzystencji”. Zaliczał do nich: pokarm, dach nad głową oraz odzież. Nawiązywał w ten sposób do klasycznej definicji Beniamina Rowntree, autora pojęcia biedy absolutnej, tj. „sytuacji, w której środki jakimi dysponują jednostki czy gospodarstwa domowe, wystarczają jedynie na zaspokojenie podstawowych potrzeb w zakresie żywienia, odzieży i mieszkania”. Cyt. za P. S ału st ow i c z, op. cit., s. 50.

${ }^{28}$ Ibidem, s. 250. 
niewykwalifikowani pracownicy najemni, osoby pracujące dorywczo oraz bezrobotne. W literaturze określa się ich mianem sproletaryzowanej warstwy miejskiej. Jej zwięzły opis znajdziemy w zaproponowanej w 2015 roku próbie nowej syntezy społeczeństwa międzywojennego. Czytamy: „Grupy takie stanowiły źródło siły roboczej do różnych zajęć, $\mathrm{w}$ tym sezonowych, a także rezerwuar zasilający margines społeczny, na ogół także siedlisko biedy"29. Fenomen strukturalnego ubóstwa obejmował również przedstawicieli zdominowanego przez Żydów żywiołu rzemieślniczego, którego symbolem pozostawały nierentowne i skutecznie opierające się próbom przymusowej modernizacji biedazakłady rozsiane po wszystkich sztetlach II RP ${ }^{30}$. W końcu, last but not least, w obszarze tym mieściła się wówczas przede wszystkim liczna grupa mieszkańców wsi, głównie z centralnych, południowych i wschodnich rejonów kraju, z reguły bezrolny (pół)proletariat wiejski ${ }^{31}$. Bez względu na ostateczne wyliczenia nie sposób nie zgodzić się z opinią sformułowaną przez badacza ówczesnych dziejów społecznych, że „zdecydowana większość ludności kraju niemal całą swoją aktywność ekonomiczną poświęcała na zaspokojenie elementarnych potrzeb życiowych, a i to w wielu przypadkach nie chroniło przed okresowym niedożywieniem, a nawet głodem"32.

We wszystkich badaniach nad zjawiskiem niedostatku podkreśla się jego relatywny charakter. Każda grupa społeczna co innego przez biedę rozumie i doświadcza jej w różnym zakresie. Oczywiście i w II RP nie istniała jednowymiarowa skala zjawiska. Trudno jest, a być może to w ogóle niemożliwie, wyrysować prostą linię podziału w obszarze dochodów, która jednoznacznie pozwalałaby wskazać ówczesną granicę ubóstwa. Niemniej historycy próbują wyznaczać takie kryteria. Cecylia Leszczyńska i Łucja Lisiecka określiły je, dla przełomu lat 20. i 30., na poziomie 1500 zł dochodu rocznego w przypadku osób czynnych zawodowo, a więc 31 zł miesięcznie na jedną osobę w czteroosobowej rodzinie ${ }^{33}$. Poniżej tego poziomu znajdowało się ponad $41 \%$ czynnych zawodowo, w tym wszyscy robotnicy rolni ${ }^{34}$. Poza tymi wyliczeniami znajdą się jednak także bezrobotni, część spośród ludzi marginesu, żebracy, ludzie szarej strefy itd.

Naturalnie poziom zamożności obywateli międzywojennej Polski, a zatem rozmiary biedy i nędzy, stale fluktuowały ${ }^{35}$. Dla tej części społeczeństwa, która nieustannie funkcjonowała w obszarach strukturalnego niedostatku czy w nędzy, zmiany

29 J. Żarnowski, Nowe spojrzenie na społeczeństwo Polski międzywojennej [w:] Społeczeństwo międzywojenne. Nowe spojrzenie, Metamorfozy Społeczne, t. 10, Warszawa 2015, s. 43.

${ }^{30} \mathrm{G}$. Z a lew s k a, Inna droga. Zmiany w strukturze spoleczno-zawodowej Żydów polskich w latach 1918-1939 [w:] Praca i spoteczeństwo..., passim.

${ }_{31}$ J. Żarnow ski, Nowe spojrzenie na społeczeństwo Polski międzywojennej..., s. 41.

32 W. Mędr zecki, Materialne uwarunkowania życia społecznego..., s. 117.

${ }_{33}$ C. Leszczyńska, Ł. Lisiecka, Dochody spoteczeństwa Drugiej Rzeczypospolitej i ich zróżnicowanie [w:] Praca i społeczeństwo..., s. 382.

${ }^{34}$ Ibidem.

${ }^{35}$ Ibidem, s. 371-373. Jeśli przyjmiemy, że dochód konsumowany minimalny w 1929 r. wynosił $100 \mathrm{zł}$, to w przypadku robotników poza rolnictwem w $1933 \mathrm{r}$. spadał do $51 \mathrm{zl}$. Na istotne zmiany wskazują też dane dot. liczby płatników podatku dochodowego. Liczba tych osób w efekcie kryzysu gospodarczego radykalnie zmalała. 
koniunktury nie odgrywały jednak istotnej roli. Wielu z jej przedstawicieli wypracowało strategie funkcjonowania, które pozwalały opierać się procesom spychającym ich na „,cmentarz socjalny”. Nierzadko, dziedzicząc swoją pozycję społeczną, korzystali z metod wypracowanych przez pokolenie rodziców. W literaturze określa się je mianem lumpenstrategii lub lumpenpracy ${ }^{36}$. Analiza biografii ówczesnych przestępców, spośród których wielu funkcjonowało w obszarze strukturalnej biedy i nędzy, ukazuje bogactwo metod służących przetrwaniu różnych etapów życia ludzi orbitujących wokół marginesu socjalnego lub na nim żyjących ${ }^{37}$. Wymienić można wśród nich: handel (wymienny) starzyzną, tandetą lub kradzionym towarem, usługi pokątne (tragarstwo, pranie, wydawanie obiadów, proste prace fizyczne - kopanie piasku itd.), życie z pomocy udzielanej przez opiekę społeczną, pracę w biedaszybach, prostytucję, cały wachlarz zachowań przestępczych: doraźne lub systematyczne kradzieże, oszustwa, fałszerstwa, w końcu żebractwo ${ }^{38}$. W przypadku wsi bywało podobnie, przy czym tam korzystano z wypracowanych już znacznie wcześniej strategii, wśród których istotne miejsce zajmowała między innymi akceptowana społecznie migracja zarobkowa.

Część spośród przedstawicieli tego środowiska - mowa o zawodowych przestępcach - rzadko szukała legalnych form zatrudnienia, a jeśli już je podejmowali, nie byli zainteresowani ich utrzymaniem. Jednocześnie zawodowi przestępcy, choć w większości urodzeni, wychowujący się i żyjący w biednych i zaniedbanych dzielnicach robotniczych, zapewne rzadko myśleli o sobie w kategoriach wykluczenia. Dzięki zapiskom $\mathrm{z}$ inwigilacji środowisk, które sporządzano w trakcie dochodzeń, wiemy, że wielu z nich aktywnie uczestniczyło w życiu społecznym ulicy, wsi czy miasta ${ }^{39}$. Pobyt w więzieniu był wkalkulowanym w ryzyko zawodowe elementem obranej strategii życiowej. W tym miejscu, z racji ich aspołecznych zachowań, poczucie deprywacji było skutkiem wykluczenia instytucjonalnego. Wyrok tylko skutecznie pogłębiał niechęć do osób, które nie wchodziły w konflikt z prawem, i wzmacniał ich aspołeczne usposobienie.

Dla wielu skazanych, w tym także doświadczonych, lecz pragnących zmienić się przestępców, pobyt $\mathrm{w}$ więzieniu stanowił istotną przeszkodę $\mathrm{w}$ powrocie do normalności. Symbolem wykluczenia instytucjonalnego i jego bolesnych konsekwencji stała się karta zwolnienia z więzienia w charakterystycznym różowym kolorze.

36 Z. Galor, op. cit., s. 38-39.

37 Notoryczny oszust Ryszard K. tak opisywał swoje życiowe perypetie: „Po wyjściu z więzienia pracowałem w różnych piekarniach, wcześnie[j] w roku 1925 byłem 2 razy aresztowany, lecz kary żadnej nie odbyłem [...] W roku 1927 wstąpiłem do spółki w Warszawie, gdzie pracowałem do 1929 r. potem pozostawałem 14 miesięcy bez pracy. W roku $1931 \mathrm{w}$ styczniu dostałem pracę w piekarni [...] gdzie pracowałem do dnia 20 VI 1931 r. od tej [pory] od 2 miesięcy pracuję dorywczo w piekarni Roguskiego". Druga połowa lat 30. w jego przypadku to już w zasadzie wyłącznie kolejne pobyty w więzieniu. APW, UŚ m.st. W., Arkusz dossier Ryszarda K., sygn. 882, 1932-1948, k. 18.

38 W. Mędrzecki, Materialne uwarunkowania życia społecznego..., s. 135. W. Mędrzecki dolicza do tej listy również wszelkie usługi pokątne, ,szarą strefę”, a więc np. służbę, pranie, pracę w biedaszybach.

39 APW, UŚ m.st. W., Arkusz dossier Dionizego O., 1931-1947, sygn. 1243, k. 19 n. Szczegóły z życia przestępców warszawskich notowane przez inwigilujących to środowisko stołecznych policjantów. 
Legitymowanie się nią, a był to często jedyny dokument, jakim dysponowali byli więźniowie, stanowiło dla wielu z nich powód do wstydu. Pobyt w więzieniu w zasadzie przekreślał szanse na podjęcie legalnej pracy, tym bardziej że instytucji wspierających byłych więźniów, poza wyjątkowo nieskutecznym „Patronatem”, w międzywojennej Polsce nie było.

Bez względu na późniejsze losy, w tym życiowe postawy i osiągnięty status materialny, wspólnym elementem biografii ludzi tworzących w II RP środowisko zawodowych przestępców był fakt, że pierwszych przestępstw dokonywali powodowani tragiczną sytuacją materialną, w jakiej znajdowali się oni i ich rodziny. Należy jednak pamiętać, że mowa tu najczęściej o przedstawicielach pokolenia urodzonego pod koniec XIX wieku. To oni tworzyli istotną część środowisk przestępczych w pierwszej dekadzie istnienia odrodzonego państwa polskiego. Ich dzieciństwo i młodość przypadły na okres przyspieszenia gospodarczego. Sytuacja ekonomiczna sprzed 1914 roku pozwalała śmielej patrzeć w przyszłość nie tylko przedstawicielom młodego pokolenia miejskiego proletariatu. Swojej szansy na lepsze życie zaczynali szukać masowo w miastach chłopscy synowie i córki, którzy z błogosławieństwem rodziców przenosili się do miast w pogoni za szczęściem. Choć więc doświadczenie życia i dorastania w niedostatku nie było obce przedstawicielom pokolenia urodzonego w latach 80. i 90. XIX wieku, to jednak wiele elementów mogło w jakimś stopniu ograniczać te czynniki, które już w II RP sprzyjały umasowieniu procesów ekskluzji. Jednym z nich stała się niewątpliwie wojna, której znaczenia w poszerzaniu obszarów wykluczenia nie sposób nie dostrzec.

Zawodowi przestępcy, z których część trudno traktować jako przedstawicieli marginesu socjalnego, stanowili jednak tylko fragment większej całości. Obok nich funkcjonowała w Polsce międzywojennej niezliczona rzesza ludzi żyjących w rzeczywistości, w której trudno jest uchwycić granicę między tym, co legalne, i tym, co nielegalne, a kradzież bywała takim samym zajęciem jak kopanie piachu nad Wisłą. Nazwanie ich „przestępczą drobnicą” byłoby daleko idącym uproszczeniem. Wielu z jej przedstawicieli biedę po prostu dziedziczyło. Część z nich to ofiary wojny (np. sieroty). Byli przedstawicielami pokolenia urodzonego w początkach XX wieku. Dorastali więc w czasie wojny bądź w niezwykle trudnej atmosferze pierwszych lat powojennych, a wiek produkcyjny osiągali tuż przed kryzysem lub w jego czasie. Część z nich stanowili migranci ze wsi, którzy w latach 20 . trafili do miast. W obawie przed powrotem, który traktowano jako kolejną formę degradacji społecznej, pozostawali w mieście i zasilali szeregi żyjących z dnia na dzień bezrobotnych.

Część przestępczych karier rozpoczynała się w momencie utraty pracy, a w zasadzie w okresie jej bezskutecznych poszukiwań. Lektura arkuszy dossier przestępców podaje setki przykładów tego typu historii ${ }^{40}$. W zdecydowanej większości z nich pojawia się słowo klucz - redukcja.

${ }^{40}$ Złodziej i oszust Rafał G. zeznawał: „Od roku 1930 byłem agentem firmy [...], lecz z powodu złych czasów nie miałem możliwości zarobkowania, zmuszony byłem uciec się do oszustwa, gdyż od dłuższego czasu choruję na chorobę weneryczną i nie mogę się leczyć" (APW, UŚ m.st. W., Arkusz dossier Rafała G., sygn. 224, 1932-1948, k. 2). Józef D. robotnik w twierdzy „Modlin”, zatrudniony z czasem jako taksator w miejskim zakładzie ubezpieczeń zeznawał ,[...] i gdy była redukcja zostałem 
Podobnie jak w przypadku zjawiska biedy, stwierdzenie o destrukcyjnym wpływie bezrobocia na charakter nastrojów społecznych w II RP czy jej struktury społecznej trąci truizmem. Brak pracy, jak piszą znawcy problematyki, „,oznaczał realne zagrożenie nie tylko dla dotychczasowego standardu życia, ale często nawet podstaw egzystencji”"41. Uwagi te dotyczą zarówno wsi, jak i miast. Historycy szacują, że w połowie lat 30. codziennie szukało pracy co najmniej $2 \mathrm{mln}$ osób w wieku produkcyjnym, w tym połowa $\mathrm{z}$ nich na wsi (wyrobnicy), a druga w mieście (głównie robotnicy najemni, bez kwalifikacji) ${ }^{42}$. Doliczyć do nich należy również kilkaset tysięcy kandydatów na pracowników umysłowych ${ }^{43}$.

Trudno wyobrazić sobie, szczególnie ze współczesnej perspektywy, sytuację, w jakiej znajdowali się gotowi do pracy ludzie, którzy w okresie kryzysu ekonomicznego nie mogli i nie mieli szans na jej zdobycie. Pamiętniki bezrobotnych, choć różnie ocenia się ich wiarygodność, ale także chłopów czy robotników pozostają wymownym świadectwem roli społecznej, jaką odgrywała praca, i tragicznych skutków, jakie mogła pociągać za sobą jej strata ${ }^{44}$. Redukcja stanowiła dla wielu symboliczny i rzeczywisty początek procesów osuwania się w dół drabiny społecznej. Chwytano się każdej okazji zarobku, z czasem szukano pomocy w instytucjach społecznych, nierzadko decydowano się na pierwsze kradzieże. Dla wielu osób bezrobocie oznaczało początek tułaczki po mieście i kraju. Stawali się włóczęgami - przedstawicielami środowiska nieakceptowanego i budzącego strach. Część z nich z czasem decydowała się przełamać barierę wstydu i zaczynała żebrać bądź w przypadku kobiet - prostytuować się.

Redukcja, względnie ograniczenie dochodów często skutkowały pogłębiającymi się problemami mieszkaniowymi. Bieda zmuszała do poszukiwania mieszkań tańszych, mniejszych i o coraz gorszym standardzie, nierzadko do tzw. mieszkania kątem. W szczycie kryzysu ekonomicznego w stołecznych schroniskach miejskich dla bezdomnych mieszkało co najmniej 10000 ludzi, a drugie tyle próbowało przetrwać w „dzielnicach” nędzy, w ruderach skleconych ze wszystkiego, co było pod ręką ${ }^{45}$.

Polityka mieszkaniowa to kolejny z ważnych czynników decydujących o rozmiarach społecznej marginalizacji w II RP. Prywatni inwestorzy, ale i państwo preferowali bardziej opłacalne budownictwo wielkomieszkaniowe. Powstawały więc przede wszystkim mieszkania duże i drogie, przeznaczone wyłącznie dla zamożnej lub średniozamożnej części społeczeństwa. Z niewielkimi wyjątkami (budownictwo spółdzielcze, robotnicze) nie budowano mieszkań małych, które byłyby w stanie

zredukowany w roku 1931. Byłem bez pracy do 1 IV 1935 r. w dniu 17 IV rb. [tj. 1935 r.] otrzymałem pracę dozorcy w Hurtowni Wódek w Ostrowi Mazowieckiej” (APW, UŚ m.st. W., Arkusz dossier Józefa D., sygn. 566, 1932-1948, k. 5).

${ }^{41}$ C. Leszczyńska, W. Mędrzecki, op. cit., s. 11.

${ }^{42}$ Ibidem.

${ }^{43}$ Ibidem.

${ }^{44}$ W. Męd rzecki, Materialne uwarunkowania życia społecznego..., s. 132.

${ }^{45}$ M. Rodak, Zjawisko bezdomności w Drugiej Rzeczypospolitej (ze szczególnym uwzględnieniem Warszawy) [w:] Od kwestii robotniczej do nowoczesnej kwestii socjalnej. Studia z polskiej polityki społecznej XX i XXI wieku, red. P. Grata, Rzeszów 2013, passim. 
zaspokoić potrzebę posiadania własnego dachu nad głową. Normą więc w dużych i średnich miastach było zjawisko kątownictwa i najem, a na wsi przeludnione chaty. Brak środków do opłacenia czynszu, pomimo istnienia rozwiązań prawnych potencjalnie chroniących lokatorów przed wyrzuceniem, dla wielu rodzin oznaczał koszmar eksmisji, za którym nierzadko szedł rozpad rodziny, depresja i rosnące przeświadczenie o znalezieniu się poza społecznym nawiasem. Poczucie wykluczenia pogłębiała specyficzna lokalizacja schronisk dla bezdomnych. Mieściły się z reguły w dzielnicach peryferyjnych, były odcięte od właściwej części miasta torami, wysypiskiem śmieci, cmentarzem czy zasiekami ${ }^{46}$.

Specyficznym przejawem destrukcyjnej siły procesów wykluczenia, które wiązać mogły się z utratą pracy i/lub eksmisją, pozostawała statystyka obejmująca przypadki zamachów i zgonów samobójczych. W okresie międzywojennym, niebezkrytycznie jednak ${ }^{47}$, wysoką skalę tego zjawiska wielu jego badaczy łączyło między innymi z pogarszającymi się warunkami życia w czasie kryzysu.

Wśród wielu powodów tak często przed wojną popełnianych samobójstw znalazł się alkohol. Oficjalne statystyki zawierają zaskakująco niskie wskaźniki spożycia alkoholu (zaledwie 1,5 1 spirytusu na osobę) ${ }^{48}$. Trudno te informacje, szczególnie jeśli skonfrontujemy je ze źródłami o innymi charakterze, traktować jako obrazujące realny stan rzeczy. Zmonopolizowane przez państwo produkcja i handel alkoholem, a przez to jego wysokie ceny, skutecznie aktywizowały szeregi pokątnych producentów między innymi bimbru. Spożycie alkoholu, szczególnie tego gatunkowo gorszego (głównie denaturatu), musiało być znacznie wyższe, niż wskazują na to oficjalne dane.

Zasadnicze w tym miejscu pytaniem brzmi: czy należy traktować ten fakt jako reakcję na wiele różnych zjawisk deprywacyjnych, czy jako ich główną przyczynę? Czy pili wykluczeni, czy może to picie wykluczało? Prawda w tym miejscu leży zapewne pośrodku. Powszechne było przekonanie, że nadużywanie alkoholu, a z czasem alkoholizm należy traktować jako zjawisko ze wszech miar sprzyjające lub towarzyszące marginalizacji.

Rozważania na temat natury społecznej ekskluzji w II RP wypada zakończyć ponurą konkluzją. Powodowane różnymi czynnikami poczucie wykluczenia musiało być wówczas doświadczeniem powszechnym. Zjawisko statusowej nieokreśloności obce zaś tylko nielicznym, głównie przedstawicielom elity finansowej

46 Ibidem, s. 56-57.

${ }^{47}$ Ówcześni psychiatrzy, względnie lekarze sądowi przekonywali, że podawanie powodów ekonomicznych jako bezpośrednich przyczyn podjęcia próby samobójczej w większości przypadków stanowi próbę ukrycia rzeczywistych przyczyn (chorób psychicznych, rozstroju nerwowego). Por. uwagi: W. Grzywo-Dąbrowski, Samobójstwo w Warszawie w r. 1934, „Czasopismo Sądowo-Lekarskie” 1935, nr 3, s. 195. Pisał: „O ile mi jest wiadomem, dane powyższe są oparte na zeznaniach rodzin samobójców wzgl. ich samych, stąd muszą być przyjmowane b. ostrożnie, gdyż otoczenie samobójcy względnie on sam z reguły są skłonni jako przyczynę samobójstwa podawać mniej w ich oczach kompromitujące przyczyny, jak np. warunki materialne itp. i dlatego ta rzekoma przyczyna bywa najczęściej podawana w wywiadach".

${ }^{48}$ T. Brzeziński, Społeczne problemy alkoholizmu w Polsce w latach 1918-1939, „Archiwum Historii i Filozofii Medycyny” 1997, nr 60, s. 350. 
i/lub politycznej, przede wszystkim heteroseksualnym Polakom, katolikom, głównie mężczyznom, $\mathrm{z}$ reguły dobrze wykształconym, mieszkającym w dużych ośrodkach miejskich. Trudno więc oprzeć się wrażeniu, że międzywojenne państwo polskie pozostawało bytem z nadmiarem obszarów wykluczenia, istotnym potencjałem teoretycznych pomysłów na ich ograniczanie (vide polityka społeczna) i znacznym deficytem wszystkiego (głównie pieniędzy), co mogłoby teorię przekuć w praktykę.

Nie ma naturalnie społeczeństw w pełni inkluzyjnych. Nawet współcześnie, w czasach względnego dobrobytu dalecy jesteśmy od sytuacji, w której można byłoby stwierdzić, że zjawisko wykluczenia to problem już marginalny. Nigdy zresztą nie zdołamy do takiej sytuacji dojść, szczególnie że pojawiają się nowe potencjalne obszary wykluczenia. Tym bardziej w II RP, w której nagromadzenie problemów nierozwiązywalnych, nierozwiązanych lub rozwiązanych w teorii potęgowało realny i symboliczny stan wykluczenia milionów jej mieszkańców. Prymat materialnych czynników wydaje się bezdyskusyjny. Ubóstwo było zjawiskiem masowym i w zasadzie w ówczesnej rzeczywistości, nawet wraz z poprawą koniunktury w II połowie lat 30., na większą skalę niedającym się zredukować.

Pierwotnie planowałem omawiać wyłącznie aktualne wówczas materialne determinanty procesów ekskluzji. Artykuł poświęcony tylko tej grupie problemów nie wyczerpałby jednak całości zagadnienia. Przyznaję, że byłoby to zadanie znacznie łatwiejsze. Badając materialny wymiar wykluczenia, można bowiem pokusić się o wskazania ówczesnej normy. Jej zasadniczymi elementami pozostawałyby praca, w zasadzie fakt jej posiadania oraz wymierny skutek, tj. pieniądze - międzywojenny fetysz. W przypadku czynników niematerialnych normę mogłyby wyznaczać obowiązujące przepisy. Opisane w tym miejscu zagadnienia wskazują jednak, że normy wyznaczone przez prawo często nijak miały się do norm rzeczywistych i społecznie akceptowanych.

Naturalnie decyzja o wykorzystaniu bardzo przecież pojemnej definicji wykluczenia może skutkować niekończącymi się poszukiwaniami obszarów, w których mogłoby występować. W skrajnym przypadku grożą nam nawet manowce ahistoryczności. Starałem się więc, wybierając przedmiot moich analiz, stosować dwa zasadnicze kryteria. Pierwsze z nich to masowość zjawiska, drugie to rzeczywisty wpływ na charakter stosunków społecznych. Omówione w tym miejscu sfery życia społecznego, które uznałem za potencjalnie determinujące procesy ekskluzji, obydwa warunki, jak mniemam, spełniały.

\section{BIBLIOGRAFIA}

\section{Źródła}

Archiwum Państwowe w Warszawie (APW), Urząd Śledczy m.st. Warszawy (UŚ m.st. W.), Arkusz dossier Heleny Zofii Kisielnickiej, sygn. 866, 1933-1948, k. 24. 
APW, UŚ m.st. Warszawy, Arkusz dossier Pawła Ł., 1935-1947, sygn. 1101, k. 2, Arkusz dossier Władysława M., 1931-1947, sygn. 1145, k. 8.

APW, UŚ m.st. W., Arkusz dossier Ryszarda K., sygn. 882, 1932-1948, k. 1.

APW, UŚ m.st. W., Arkusz dossier Dionizego O., 1931-1947, sygn. 1243.

APW, UŚ m.st. W., Arkusz dossier Rafała G., sygn. 224, 1932-1948.

APW, UŚ m.st. W., Arkusz dossier Józefa D., sygn. 566, 1932-1948.

\section{Opracowania}

Brykczyński P., Gotowi na przemoc. Mord, antysemityzm i demokracja w międzywojennej Polsce, Warszawa 2017.

Brzeziński T., Spoleczne problemy alkoholizmu w Polsce w latach 1918-1939, „Archiwum Historii i Filozofii Medycyny" 1997, nr 60.

Chojnowski A., Koncepcje polityki narodowościowej rządów polskich w latach 19211939, Wrocław-Warszawa-Kraków-Gdańsk 1979.

Chylak K., Ubezpieczenia społeczne i zaopatrzenia emerytalne w II Rzeczypospolitej, Warszawa 2017.

Galor Z., Margines społeczny a margines socjalny $i$ margines strukturalny. U podstaw socjologii marginalizacji w świetle badań poznańskich z lat 2010-2013 [w:] Życie na skraju. Marginesy społeczne wielkiego miasta, red. Z. Galor, B. Goryńs ka-B it tne r, S. Kalinowski, Bielefeld 2014.

Grzywo-Dąbrowski W., Samobójstwo w Warszawie w r. 1934, „Czasopismo Sądowo-Lekarskie" 1935, nr 3.

He n s c hel H., Jabłonna als Erinnerungsikone: Juden in den polnischen Streitkräften 1918 1939, „Jahrbuch des Simon-Dubnow-Instituts” 2010, nr 9.

Kęs i k J., Wojsko polskie a społeczeństwo w Drugiej Rzeczypospolitej [w:] Państwo i społeczeństwo Drugiej Rzeczypospolitej, Metamorfozy Społeczne, t. 8, Warszawa 2014.

Kij ek K., Dzieci modernizmu. Świadomość, kultura i socjalizacja polityczna młodzieży żydowskiej w II Rzeczypospolitej, Wrocław 2017.

Kny s e l-K o peć R., Polityka społeczna Drugiej Rzeczypospolitej wobec kobiet [w:] Państwo i społeczeństwo Drugiej Rzeczypospolitej, Metamorfozy Społeczne, t. 8, Warszawa 2014.

Leszczyńska C., Lis iecka Ł., Dochody społeczeństwa Drugiej Rzeczypospolitej i ich zróżnicowanie [w:] Praca i społeczeństwo Drugiej Rzeczypospolitej, Metamorfozy Społeczne, t. 9, Warszawa 2014.

Leszczyńska C., Mędrzecki W., Wstęp [w:] Praca i spoleczeństwo Drugiej Rzeczypospolitej, Metamorfozy Społeczne, t. 9, Warszawa 2014.

Linkiewicz O., Lokalność i nacjonalizm. Społeczności wiejskie w Galicji Wschodniej w dwudziestoleciu międzywojennym, Kraków 2018.

Mędrzecki W., Kresowy kalejdoskop. Wędrówki przez ziemie wschodnie Drugiej Rzeczypospolitej 1918-1939, Kraków 2018.

M ę drze c ki W., Materialne uwarunkowania życia społecznego [w:] Społeczeństwo międzywojenne. Nowe spojrzenie, Metamorfozy Społeczne, t. 10, Warszawa 2015.

Pamiętniki chłopów, Warszawa 1935.

P ietrzak M., Sytuacja prawna kobiet w Drugiej Rzeczypospolitej [w:] Równe prawa i nierówne szanse, red. A. Ż arnow s ka, A. S zw arc, Warszawa 2000.

Rodak M., Zjawisko bezdomności w Drugiej Rzeczypospolitej (ze szczególnym uwzględnieniem Warszawy) [w:] Od kwestii robotniczej do nowoczesnej kwestii socjalnej. Studia z polskiej polityki społecznej XX i XXI wieku, red. P. Grata, Rzeszów 2013. 
Sałustowicz P., Bieda, marginalizacja $i$ wykluczenie społeczne [w:] Życie na skraju marginesy społeczne wielkiego miasta, red. Z. Galor, B. Goryń ska-Bittner, S. Kalinowski, Bielefeld 2014.

Sierakowska K., Śmierć, wygnanie, głód $w$ dokumentach osobistych. Ziemie polskie w latach Wielkiej Wojny 1914-1918, Warszawa 2015.

S zy manow ska J., Peryferyjna dzielnica wielkiego miasta. Próba charakterystyki Ochoty, dzielnicy Warszawy na podstawie badań przeprowadzonych $w$ czasie zapisów szkolnych w 1934 r., „Przegląd Socjologiczny” 1936, nr 1-2.

Zalewska G., Inna droga. Zmiany w strukturze społeczno-zawodowej Żydów polskich w latach 1918-1939 [w:] Praca i społeczeństwo Drugiej Rzeczypospolitej, Metamorfozy Społeczne, t. 9, Warszawa 2014.

Żarnows ka A., Obywatelki II Rzeczypospolitej [w:] Równe prawa i nierówne szanse, red. A. Żarnowska, A. S zw arc, Warszawa 2000.

Żarnow ski J., Bieda i dostatek 1918-1939 [w:] Nędza i dostatek na ziemiach polskich od średniowiecza po XX wiek, red. J. S zte tyłła, Warszawa 1992.

Żarnowski J., Nowe spojrzenie na społeczeństwo Polski międzywojennej [w:] Społeczeństwo międzywojenne. Nowe spojrzenie, red. W. Mę dr ze c ki, J. Ż arnow s ki, Metamorfozy Społeczne, t. 10, Warszawa 2015. 